Research Article

\title{
Correlation of Vitamin D deficiency with Type 2 diabetes and metabolic traits in the Indian population
}

\author{
Ashish H. Bajaj ${ }^{1 *}$, Suchanda Gadre ${ }^{1}$, Sangita Sukumaran², Deepali Vidhate ${ }^{3}$
}

\begin{abstract}
${ }^{1}$ Department of Pharmacology,
D. Y. Patil University,

School of Medicine, Nerul, Navi Mumbai, Maharashtra, India, ${ }^{2}$ Department of Pharmacology, Terna Medical College, Nerul, Navi Mumbai, Maharashtra, India,

${ }^{3}$ Department of Biochemistry, D. Y. Patil University, School of Medicine, Nerul, Navi Mumbai, Maharashtra, India
\end{abstract}

Received: 21 October 2015 Accepted: 15 November 2015

\section{*Correspondence to: \\ Dr. Ashish H. Bajaj, Email: ashishbajaj88@gmail. com}
Copyright: (C) the author(s), publisher and licensee Medip Academy. This is an open- access article distributed under the terms of the Creative Commons Attribution Non- Commercial License, which permits unrestricted non- commercial use, distribution, and reproduction in any medium, provided the original work is properly cited.

\begin{abstract}
Background: In India, $30-50 \%$ of children and $50-80 \%$ of adults are Vitamin D deficient. Limited data exists to assess the association of Vitamin D status, Type 2 diabetes (T2D), and metabolic traits in Indians. This study was conducted to assess the correlation of Vitamin D deficiency with T2D and metabolic risk factors in the Indian population.

Methods: Patients of either gender visiting medicine outpatient department over a period of 1-year and with Vitamin D deficiency (levels $<20 \mathrm{ng} / \mathrm{ml}$ ), not taking Vitamin D supplements and having T2D were selected for the study. Participants were tested for serum Vitamin D, fasting blood sugar, and lipid profile parameters. Correlation between Vitamin D deficiency and blood sugar and Vitamin D deficiency and lipid profile was assessed using Pearson's correlation test.

Results: Out of 144 subjects, number of diabetic patients were $74(51.38 \%)$ and non-diabetic patients were 70 (48.61\%). Among diabetic patients, 10/74 (13.51\%) were Vitamin D deficient and among non-diabetic patients, 20/70 (28.57\%) were Vitamin D deficient. There was an inverse correlation between Vitamin D and total cholesterol $(\mathrm{p}=0.01)$ and Vitamin $\mathrm{D}$ and low-density lipoprotein $(\mathrm{p}=0.01)$, and it was statistically significant $(\mathrm{p}<0.05)$.
\end{abstract}

Conclusion: Assessment of Vitamin D levels can be useful in diabetic patients as its deficiency is associated with T2D.

Keywords: Vitamin D, Type 2 diabetes mellitus, Lipid profile, Serum cholesterol

\section{INTRODUCTION}

Vitamin D deficiency, as reflected by circulating 25-hydroxyvitamin D (25[OH]D) levels $<20 \mathrm{ng} / \mathrm{ml}$, is prevalent in as many as one-half of middle-aged to elderly adults in developed countries. ${ }^{1,2}$ The ubiquitous distribution of Vitamin D receptors in the body, controlled by nearly 3000 genes, ${ }^{3,4}$ suggest that a deficiency could have widespread health consequences. Thus, understanding the characteristics that promote Vitamin D deficiency in the general population has important clinical implications. Vitamin D deficiency is estimated to affect over 1 billion people worldwide, ${ }^{1}$ and its prevalence is increasing in conjunction with Type 2 diabetes (T2D), obesity, and derangements in metabolic traits. Recent studies have examined the physiological functions of Vitamin D beyond its well-established role in musculoskeletal health. ${ }^{5}$ In addition to findings of oncologic ${ }^{4}$ and immunologic ${ }^{5}$ associations, Vitamin D deficiency is associated with metabolic derangements and T2D. ${ }^{6-8}$ Although 1, 25(OH)D is the active form of Vitamin D, it is not suitable for measuring Vitamin D serum level. 25(OH)D has a longer half-life and it can more precisely show the food intake and skin production of Vitamin D. A serum level of $<20 \mathrm{ng} / \mathrm{ml}(50 \mathrm{nmol} / \mathrm{L}) 25(\mathrm{OH}) \mathrm{D}$ is considered as Vitamin D deficiency, between 20 and $30 \mathrm{ng} / \mathrm{ml}$ as its insufficient level and higher than $30 \mathrm{ng} / \mathrm{ml}$ as its desirable or sufficient level. ${ }^{9-11}$ 
Vitamin D status is known to be poor among Indians; ${ }^{10}$ however, limited data exists to assess the implications of T2D on Vitamin D status and metabolic traits in Indians. This study was conducted to assess the correlation of Vitamin D deficiency with T2D and metabolic risk factors in the Indian population.

\section{Aims and objectives}

- To evaluate the association of Vitamin D deficiency and T2D

- To examine the association of Vitamin D deficiency and metabolic traits.

\section{METHODS}

This prospective study was conducted in D. Y. Patil University, School of Medicine over a period of 1-year. Institutional Ethics Committee approval was obtained before starting the study. The study procedure was explained to the patients who volunteered and fulfilled the eligibility criteria. Informed consent was taken from the subjects before starting the study.

\section{Study procedure}

Out of the screened patients, those fulfilling the eligibility criteria were invited into the study. After explaining them the details of the study, written informed consent was taken from each of the participants. For the assessment of all the required parameters of the study, $10 \mathrm{ml}$ of blood was collected after a fasting period of $12 \mathrm{hrs}$ from both the groups, i.e., from diabetic and non-diabetic patients and the following tests were assessed:

- $\quad$ Fasting blood glucose

- Serum 25(OH)D levels

- $\quad$ Lipid profile, i.e., triglyceride, cholesterol, high-density lipoprotein (HDL), low-density lipoprotein (LDL), very LDL (VLDL).

A detailed history regarding age, sex, smoking habits, alcohol consumption, blood pressure, diet, body mass index (BMI), waist circumference, and waist to hip ratio was noted down, and patients were also asked whether they were on any Vitamin D supplements.

Duration: 1 year.

Sample size: 144 patients (74 diabetic patients and 70 normoglycemic controls).

\section{Eligibility criteria}

\section{Inclusion criteria}

1. Either gender 18 years and above who have Vitamin D deficiency with serum $25(\mathrm{OH}) \mathrm{D}<20 \mathrm{ng} / \mathrm{ml}$
2. $\mathrm{T} 2 \mathrm{D}$

3. Sign written informed consent.

\section{Exclusion criteria}

1. Impaired fasting glucose or impaired glucose tolerance test

2. Type 1 diabetes or secondary diabetes

3. Subjects taking Vitamin D supplementation

4. Pregnant and nursing mothers.

\section{Statistical analyzes}

Data for anthropometric and metabolic characteristics of the study subjects was expressed as mean \pm standard deviation or $\mathrm{n}(\%)$. Student's t-test was used for comparison of parameters in two groups. Regression analysis was applied to assess the impact of Vitamin D status on T2D and metabolic traits.

\section{RESULTS}

\section{Demographic and laboratory data}

$25(\mathrm{OH}) \mathrm{D}$ was quantified in a total of 144 patients with a mean age of $55.95 \pm 10.95$ in the diabetic patients and $44.42 \pm 16.79$ in the non-diabetic patients. Among the participants, 52.7\% were males in the diabetic group and $54.2 \%$ were males in the non-diabetic group. Furthermore, $51.38 \%$ had T2D while $48.61 \%$ were non-diabetics (Table 1 ).

\section{Prevalence of Vitamin D deficiency}

Levels of 25(OH)D as assessed in 144 patients showed that more number of patients in the non-diabetic group were Vitamin D deficient as compared to the diabetic group (Table 2).

\section{Association of Vitamin D deficiency with metabolic traits}

Analyzes were performed to assess the impact of Vitamin D status on T2D, and the related metabolic traits (Table 3). $\mathrm{p}<0.05$ was considered as significant.

\section{DISCUSSION}

Vitamin D levels and its association with various factors such as T2D mellitus and other metabolic traits are gaining interest in upcoming research fields. Its levels prove to be important factors governing various health implications. In this study, a trend of Vitamin D deficiency in both diabetics and non-diabetics was observed, with $13.51 \%$ diabetics found to be Vitamin D deficient and $28.57 \%$ of non-diabetics as deficient in Vitamin D. Thus, more participants in nondiabetic group were deficient in Vitamin D which contrary to the outcome in other study which showed that out of the total 1765 participants, the T2D cases $(50.2 \%)$ had a significantly 
Table 1: Demographic data and laboratory results in diabetic and non-diabetic patients.

\begin{tabular}{|lcc|} 
Parameters & $\begin{array}{c}\text { Diabetics } \\
(\mathbf{n}=\mathbf{7 4})\end{array}$ & $\begin{array}{c}\text { Non-diabetics } \\
(\mathbf{n}=\mathbf{7 0})\end{array}$ \\
\hline Age & $55.95 \pm 10.95$ & $44.42 \pm 16.79$ \\
\hline Males & 39 & 38 \\
\hline Females & 35 & 32 \\
\hline FBS $(\mathrm{mg} / \mathrm{dl})$ & $160.88 \pm 69.75$ & $92.95 \pm 10.22$ \\
\hline Total cholesterol (mg/dl) & $193.13 \pm 50.85$ & $171.67 \pm 34.47$ \\
\hline Triglycerides (mg/dl) & $163.48 \pm 86.73$ & $110.34 \pm 65.55$ \\
\hline HDL $(\mathrm{mg} / \mathrm{dl})$ & $40.40 \pm 11.87$ & $38.98 \pm 9.49$ \\
\hline LDL $(\mathrm{mg} / \mathrm{dl})$ & $117.91 \pm 48.24$ & $107.35 \pm 29.23$ \\
\hline VLDL $(\mathrm{mg} / \mathrm{dl})$ & $32.09 \pm 17.55$ & $22.03 \pm 13.16$ \\
\hline BMI $\left(\mathrm{kg} / \mathrm{m}^{2}\right)$ & $25 \pm 4.63$ & $24 \pm 4.12$ \\
\hline Waist circumference $(\mathrm{cm})$ & $95.64 \pm 9.9$ & $89.62 \pm 12.25$ \\
\hline
\end{tabular}

Table 1 summarizes the distribution of parameters in relation to the mean and SD. It can be seen that in the diabetic group the mean $\pm \mathrm{SD}$ is higher in all the parameters than in the non-diabetic group. This shows that increase in FBS and lipid profile parameters itself is an indicator of diabetes progression. Furthermore, the mean $\pm \mathrm{SD}$ of $\mathrm{BMI}$ in the diabetic group is $25 \pm 4$.63, which is higher than the BMI $24 \pm 4.12$ in the non-diabetic group. Mean \pm SD for waist circumference are higher in the diabetic group (95.64 \pm 9.9$)$ than in the non-diabetic group (89.62 \pm 12.25$)$. FBS: Fasting blood sugar, HDL: High-density lipoprotein, LDL: Low-density lipoprotein, VLDL: Very low-density lipoprotein, BMI: Body mass index, SD: Standard deviation

\section{Table 2: Vitamin D levels in diabetic and non-} diabetic patients.

\begin{tabular}{|llc|}
\hline $\begin{array}{l}\text { Vitamin D levels } \\
(\mathbf{n g} / \mathbf{d l})\end{array}$ & $\begin{array}{l}\text { Diabetics } \\
\mathbf{n = 7 4}(\mathbf{\%})\end{array}$ & $\begin{array}{c}\text { Non-diabetics } \\
\mathbf{n = 7 0}(\mathbf{\%})\end{array}$ \\
\hline$\leq 20$ (deficient) & $10(13.51)$ & $20(28.57)$ \\
\hline $21-29$ (insufficient) & $23(31.08)$ & $17(24.28)$ \\
\hline$\geq 30$ (sufficient) & $41(55.40)$ & $33(47.14)$ \\
\hline
\end{tabular}

Table 2 summarizes the levels of Vitamin D in diabetic and nondiabetic patients. A total of $13.51 \%$ patients in the diabetic group while $28.57 \%$ patients in the non-diabetic group were classified as Vitamin D deficient $(\leq 20 \mathrm{ng} / \mathrm{dl})$. Around $55.4 \%$ patients in the diabetic group and $47.14 \%$ patients in the non-diabetic group had sufficient ( $\geq 30 \mathrm{ng} / \mathrm{dl}$ ) Vitamin D levels. It can be observed that number of patients are having sufficient Vitamin D levels in the diabetic group as compared to the non-diabetic group

higher prevalence of Vitamin D deficiency (83.5\%) when compared to non-diabetic patients $(68 \%))^{11,14,15}$ There was an inverse correlation between $25(\mathrm{OH}) \mathrm{D}$ and fasting blood sugar (FBS), serum triglycerides, HDL, and VLDL; however, the values were not statistically significant which is similar to the findings of the study conducted by Braun et al. in 2012 which reported a highly significant, inverse association of serum $25(\mathrm{OH}) \mathrm{D}$ with T2D, FBS, and the lipid profile parameters. ${ }^{16-19}$

In our study, there was an inverse correlation between Vitamin D and lipid profile and statistically significant
Table 3: Correlation between 25(OH)D and biochemical parameters.

\begin{tabular}{|lcc|}
\hline $\begin{array}{l}\text { Biochemical } \\
\text { parameter }\end{array}$ & \multicolumn{1}{c|}{$\begin{array}{c}\text { Pearson's correlation } \\
\text { coefficient }(\mathbf{r})\end{array}$} \\
\cline { 2 - 3 } & $\begin{array}{c}\text { Diabetics } \\
(\mathbf{n}=\mathbf{7 4})\end{array}$ & $\begin{array}{c}\text { Non-diabetics } \\
(\mathbf{n}=\mathbf{7 0})\end{array}$ \\
\hline Fasting blood glucose & -0.1897 & 0.0789 \\
\hline $\mathrm{p}$ value & $0.51(\mathrm{NS})$ & $0.10(\mathrm{NS})$ \\
\hline Total cholesterol & -0.2790 & -0.0538 \\
\hline $\mathrm{p}$ value & $0.01^{*}$ & $0.65(\mathrm{NS})$ \\
\hline Serum triglycerides & -0.12691 & -0.0935 \\
\hline $\mathrm{p}$ value & $0.28(\mathrm{NS})$ & $0.44(\mathrm{NS})$ \\
\hline HDL & 0.079536 & 0.1379 \\
\hline $\mathrm{p}$ value & $0.50(\mathrm{NS})$ & $0.25(\mathrm{NS})$ \\
\hline LDL & -0.2971 & 0.0207 \\
\hline $\mathrm{p}$ value & $0.01 *$ & $0.86(\mathrm{NS})$ \\
\hline VLDL & -0.1292 & -0.0911 \\
\hline $\mathrm{p}$ value & $0.27(\mathrm{NS})$ & $0.45(\mathrm{NS})$ \\
\hline
\end{tabular}

Table 3 summarizes that an inverse correlation was found in the diabetic group between Vitamin D and serum total cholesterol $(\mathrm{p}=0.01)$ and Vitamin D and serum LDL $(\mathrm{p}=0.01)$ levels, and it was statistically significant. No significant correlation was found between Vitamin D and serum triglycerides, serum HDL, and serum VLDL in the diabetic and non-diabetic groups. ${ }^{*} \mathrm{p}<0.05$ - significant. NS: Not significant, 25(OH)D: 25-hydroxy Vitamin D, LDL: Low-density lipoprotein, VLDL: Very lowdensity lipoprotein

$(\mathrm{p}<0.05)$ association was found between Vitamin D and total cholesterol and between Vitamin D and LDL. Thus, our study shows that diabetic patients had higher levels of total cholesterol, triglycerides, and LDL as compared to the non-diabetic group. This coincides with the findings of a study conducted by Simonen et al. in 2011. ${ }^{12}$ A negative correlation was found between Vitamin D levels and blood sugar levels, i.e., more number of diabetic patients had higher levels of Vitamin D.

We did not consider blood pressure measurements, which could have helped in a better correlation between Vitamin D levels and diabetes. Another limitation of this study was a small sample size.

Assessment of levels of Vitamin D can thus be a useful predictor for the occurrence of derangements in the metabolic traits in a particular population. Proper treatment of Vitamin D deficiency can thus help in improving metabolic traits and the diabetic status of the patients. It can be provided by Vitamin D supplementation by fortifying staple foods with Vitamin D and it is the most viable population based strategy to achieve Vitamin D sufficiency.

\section{ACKNOWLEDGMENTS}

We thank D. Y. Patil University, Navi Mumbai for funding the study. We also thank Dr. Thankamani Marar, Professor, 
D. Y. Patil School of Biotechnology and Bioinformatics for helping with enzyme-linked immunosorbent assays testing and analysis of data.

\section{Funding: D. Y. Patil University}

Conflict of interest: None declared

Ethical approval: The study was approved by the Institutional Ethics Committee

\section{REFERENCES}

1. Holick MF, Chen TC. Vitamin D deficiency: a worldwide problem with health consequences. Am J Clin Nutr. 2008;87(4):1080S-6.

2. Ramagopalan SV, Heger A, Berlanga AJ, Maugeri NJ, Lincoln MR, Burrell A, et al. A ChIP-seq defined genomewide map of vitamin $\mathrm{D}$ receptor binding: associations with disease and evolution. Genome Res. 2010;20(10):1352-60.

3. Heaney RP. Long-latency deficiency disease: insights from calcium and vitamin D. Am J Clin Nutr. 2003;78(5):912-9.

4. Davis CD. Vitamin D and cancer: current dilemmas and future research needs. Am J Clin Nutr. 2008;88(2):565S-9.

5. Aranow C. Vitamin D and the immune system. J Investig Med. 2011;59(6):881-6.

6. Mitri J, Muraru MD, Pittas AG. Vitamin D and type 2 diabetes: a systematic review. Eur J Clin Nutr. 2011;65(9):1005-15.

7. Vacek JL, Vanga SR, Good M, Lai SM, Lakkireddy D, Howard PA. Vitamin D deficiency and supplementation and relation to cardiovascular health. Am J Cardiol. 2012;109(3):359-63.

8. Renzaho AM, Halliday JA, Nowson C. Vitamin D, obesity, and obesity-related chronic disease among ethnic minorities: a systematic review. Nutrition. 2011;27(9):868-79.

9. Holick MF. Vitamin D deficiency. N Engl J Med. 2007;357(3):266-81.

10. Harinarayan CV, Ramalakshmi T, Venkataprasad U.
High prevalence of low dietary calcium and low Vitamin D status in healthy south Indians. Asia Pac J Clin Nutr. 2004;13(4):359-64.

11. Braun TR, Been LF, Blackett PR, Sanghera DK. Vitamin D deficiency and cardio-metabolic risk in a north Indian community with highly prevalent type 2 diabetes. J Diabetes Metab. 2012;3.

12. Simonen PP, Gylling HK, Miettinen TA. Diabetes contributes to cholesterol metabolism regardless of obesity. Diabetes Care. 2011;25(9):1511-5.

13. International Diabetes Federation. IDF Diabetes Atlas. 5th Edition. Brussels, Belgium: International Diabetes Federation; 2011

14. Liel Y, Ulmer E, Shary J, Hollis BW, Bell NH. Low circulating vitamin D in obesity. Calcif Tissue Int. 1988;43(4):199-201.

15. Hamilton B. Vitamin D and human skeletal muscle. Scand J Med Sci Sports. 2010;20(2):182-90.

16. Parikh SJ, Edelman M, Uwaifo GI, Freedman RJ, SemegaJanneh M, Reynolds J, et al. The relationship between obesity and serum 1,25-dihydroxy vitamin D concentrations in healthy adults. J Clin Endocrinol Metab. 2004;89(3):11969.

17. Oh J, Weng S, Felton SK, Bhandare S, Riek A, Butler B, et al. 1,25(OH)2 vitamin d inhibits foam cell formation and suppresses macrophage cholesterol uptake in patients with type 2 diabetes mellitus. Circulation. 2009;120(8):687-98.

18. Hyppönen E, Power C. Vitamin D status and glucose homeostasis in the 1958 British birth cohort: the role of obesity. Diabetes Care. 2006;29(10):2244-6.

19. Palomer X, González-Clemente JM, Blanco-Vaca F, Mauricio D. Role of vitamin D in the pathogenesis of type 2 diabetes mellitus. Diabetes Obes Metab. 2008;10(3):185-97.

Cite this article as: Bajaj $\mathrm{AH}$, Gadre $\mathrm{S}$, Sukumaran $\mathrm{S}$, Vidhate D. Correlation of Vitamin D deficiency with Type 2 diabetes and metabolic traits in the Indian population. Int J Basic Clin Pharmacol 2015;4:1224-7. 